\title{
"A GUERRA NÃO ACABOU": A ESCRITA E A DISPUTA DO PASSADO SOBRE A LUTA ARMADA NO ARAGUAIA ATRAVÉS DAS MEMÓRIAS DOS MILITARES
}

Wellington Sampaio da Silva

O título do artigo "A guerra não acabou!", parece num primeiro num primeiro olhar, estranho, se não fora de conotação histórica. Mas em relação aos acontecimentos envolvendo a chamada Guerrilha do Araguaia há evidências bastantes contundentes. Como assim? Evidentemente que em termos bélicos, ou seja, de luta envolvendo armas de fogo e homens se digladiando de lados opostos (guerrilheiros e militares), a guerra foi encerrada na terceira expedição militar a área em dezembro de 1974. Contudo, se levarmos em consideração as construções das memórias sobre essa guerra, encontramos evidências de sua presença inclusive no tempo presente.

Nesse sentido, propomos nesse artigo analisar a escrita de alguns militares participantes direta e/ou indiretamente no combate a luta armada no Araguaia. Por que resolveram publicar suas reminiscências? Ou seja, o que os motivou? Em qual contexto suas obras foram produzidas? Quais as versões construídas por esses personagens? Quais caminhos esses personagens buscaram para publicar essas versões? São algumas questões que pretendemos responder ao longo desse ensaio.

A escrita dos militares acerca da Guerrilha do Araguaia é algo mais recente, se tomarmos como referência as narrativas construídas pelo Partido Comunista do Brasil (PC do B) que, já durante a guerra, elaborou diários, comunicados aos moradores locais, cartas, manifestos tornando esses documentos públicos $e$, ao longo dos anos, jornalistas $e$ intelectuais de esquerda analisaram $e$ avaliaram essa experiência de guerrilha, tornando-a conhecida para a sociedade através de vários livros. ${ }^{2}$ No caso dos militares, a iniciativa de publicar suas memórias sobre a Guerrilha do Araguaia através de livros acontece a partir da década de 1990, isto é, quase duas décadas após o fim do conflito armado no Araguaia. Exemplo dessa prática é o livro do capitão-aviador Pedro Corrêa Cabral, Xambioá: guerrilha no Araguaia, publicado através da Editora Record em 1993. ${ }^{3}$

Para os militares, a guerra já havia sido vencida pelas armas, e não havia, necessariamente, necessidade de ficar rememorando tais batalhas, mas esquecê-las. Contudo, os "perdedores", diga-se os militantes de esquerda, optaram por uma postura diferente. Passaram ao longo dos anos após o final da luta armada a escreverem suas memórias, publicarem livros, concederem entrevistas passando a divulgar para a sociedade suas versões para o período de exceção no geral, e para a luta armada, em específico. Diante dessa prática e temendo perder essa outra guerra, a de memórias, os militares entram na disputa acerca do passado desse período da história do Brasil. Passam a construir suas versões, publicam livros e se lançam nessa nova guerra, agora através da escrita. Em relação à noção de guerra de memórias, nos apropriamos desse termo usado por Pierre Ansart no artigo "História $e$ memória dos ressentimentos," "no qual o autor ao discutir o panorama político da França no período pós Segunda Guerra Mundial, o caracterizou a partir da polarização de duas forças políticas hegemônicas e rivais - de um lado o governo do general De Gaulle, exaltando nas cerimônias oficiais o nacionalismo e a França livre, e do outro, o Partido Comunista Francês, enfatizando o papel desempenhado pela resistência comunista e a URSS na vitória aliada na guerra. ${ }^{5}$ Dessa forma, suas

\footnotetext{
${ }^{1}$ Doutorando em História Social da Universidade Federal do Ceará (UFC) e Professor do Ensino Básico, Técnico e Tecnológico do Instituto Federal do Tocantins (IFTO-Campus Araguaína). E-mail: sampaio.well@bol.com.br

${ }^{2}$ Dentre os livros escritos e publicados por jornalistas destacamos: DÓRIA, Palmério et al., A Guerrilha do Araguaia. História imediata. No 1, São Paulo: Alfa-Omega, 1978; PORTELA, Fernando. Guerra de Guerrilhas no Brasil. 1a ed. São Paulo: Global Editora, 1979; Já no que concerne aos livros escritos por intelectuais de esquerda temos: POMAR, Wladimir. Araguaia: o partido e a guerrilha - Documentos inéditos. São Paulo: Brasil Debates, 1980; GORENDER, Jacob. Combate nas trevas - a esquerda brasileira: das ilusões perdidas à luta armada. $3^{\mathrm{a}}$ ed. São Paulo: Ática, 1987.

${ }^{3}$ CABRAL, Pedro Corrêa. Xambioá: Guerrilha no Araguaia. Rio de Janeiro: Record, 1993.

${ }^{4}$ ANSART, Pierre. História e memória dos ressentimentos. In: BRESCIANE, Stella e NAXARA, Márcia (orgs.). História e (res)sentimento: indagações sobre uma questão sensível. Campinas: Editora da Unicamp, 2004.

${ }^{5}$ ANSART, História e memória dos ressentimentos, p. 32.
} 
narrativas constroem a partir de acusações, revanches e ressentimentos versões heterogêneas e opostas para esse período da história francesa. E no caso da Guerrilha do Araguaia? Encontramos nas narrativas de memórias indícios semelhantes da presença de acusações, ressentimentos $e$ às vezes sentimentos de revanchismo por parte dos personagens que participaram da mesma.

Há várias obras publicadas por militares sobre essa questão. Escolhemos para tessitura desse artigo, três livros que representam, a nosso ver, as disputas em torno da memória acerca da luta armada no Araguaia: A guerrilha do Araguaia - revanchismo: a grande verdade, escrita pelo coronel Aluísio Madruga de Moura e Souza, Bacaba: memórias de um guerreiro de selva da Guerrilha do Araguaia, do tenente-coronel José Vargas Jiménez e Guerrilha do Araguaia: relato de um combatente, escrita pelo coronel Licio Augusto Ribeiro Maciel. ${ }^{6}$

\section{A escrita da Guerrilha do Araguaia centrada na ideia de revanchismo}

Em 2002, o coronel Aluísio Madruga de Moura e Souza publicou o seu livro A guerrilha do Araguaia - revanchismo: a grande verdade. Nele, como o próprio subtítulo da obra sugere, a ideia de revanchismo constitui o cerne de sua narrativa. Segundo o dicionário de política revanchismo "é um comportamento político tendente a anular as desvantagens de uma derrota sofrida". ${ }^{7}$ Ora, no caso da Guerrilha do Araguaia, esse comportamento estaria presente, segundo os militares, nos ex-militantes do PC do B e também naqueles que aceitam a sua versão para esse acontecimento. Dessa maneira, a vitória pelas armas das Forças Armadas não significou uma vitória na "batalha de memória" instituída após o conflito. Nessa outra batalha, a da memória, inicialmente, os militantes do PC do B e seus partidários estavam saindo vitoriosos. Era necessário, portanto, revidar na mesma moeda. E para isso, alguns militares iniciaram a prática de publicar suas memórias através de livros. Narrar sua versão para esse acontecimento em resposta "as acusações" dos seus adversários. Assim, a obra do coronel Aluísio Madruga seria uma resposta à prática do revanchismo presente na versão das esquerdas.

Outro aspecto a ser considerado na narrativa do coronel Aluísio Madruga e que também evidencia essa disputa pelo passado é a tentativa de se construir uma versão verdadeira para a chamada "Contrarrevolução de 1964". Segundo ele, existe uma versão que foi construída pelas esquerdas e que se tornou hegemônica - "A grande mentira", e é necessário desconstruí-la. Nesse contexto, iniciando sua narrativa, enfatiza o objetivo da obra:

O objetivo não é outro senão o de contribuir para evitar que os comunistas brasileiros, de todos os matizes, permaneçam contando "UMA GRANDE MENTIRA": a respeito dos acontecimentos da Contra-Revolução de 1964; sobre porque ela foi desencadeada; sobre as razões pelas quais durou mais de duas décadas. Tem ainda o objetivo de homenagear de forma permanente àqueles que enfrentaram o flagelo do terrorismo comunista e também às suas famílias $(\ldots)^{8}$

Assim, revanchismo e verdade são dois conceitos bastante evidentes em toda a narrativa do autor. Para construir sua tese, Aluísio Madruga discute o movimento comunista partindo das Internacionais até as origens e formação do Partido Comunista Brasileiro. ${ }^{9}$ No tocante a história do comunismo no Brasil, o autor faz uma análise que, a nosso ver, não deixa de ser historicista, buscando as origens desse movimento no país. Nesse sentido, faz uma discussão da influência das ideias comunistas a partir da vinda dos imigrantes italianos e espanhóis. Eles teriam influenciado com ideias anarquistas o movimento operário em nosso país. Assim, em 1908 no Rio de Janeiro foi criada a Confederação Operária Brasileira (COB), e em 1918, teriam surgido os sintomas da formação do Partido Comunista

\footnotetext{
${ }^{6}$ Além dos livros citados, pode-se considerar dentro dessa mesma perspectiva as seguintes obras: GIORDANI, Marco Pollo. Brasil Sempre. Porto Alegre, RS: Tchê, 1986; USTRA, Carlos Alberto Brilhante. Rompendo o silêncio. Brasília: Editerra Editorial, 1987; USTRA, Carlos Alberto Brilhante. A verdade sufocada: a história que a esquerda não quer que o Brasil conheça. Brasília: Ser, 2006; AUGUSTO, Agnaldo Del Nero; MACIEL, Licio; NASCIMENTO, José Conegundes do (orgs). Orvil: tentativas de tomada do poder. São Paulo: Schoba, 2012.

${ }^{7}$ BOBBIO, Norberto; MATTEUCI, Nicola; PASQUINO, Gianfranco. Dicionário de política. 6 ${ }^{\mathrm{a}}$ ed. Brasília, DF: Editora Universidade de Brasília, 2003.

${ }^{8}$ MOURA E SOUZA, Aluísio Madruga de. Guerrilha do Araguaia - revanchismo: a grande verdade. Edição do Autor: Brasília, 2002. p. 12. (Grifos do autor do livro).

${ }^{9}$ MOURA E SOUZA, Guerrilha do Araguaia, p. 16-33. 
no Brasil, embora ele fosse institucionalizado em $1922 .{ }^{10}$ As argumentações do coronel Aluísio Madruga parte sempre de um lugar institucional - Centro de Informações do Exército (CIE) - o qual a tradição anticomunista constituiu uma prática entre os seus membros. ${ }^{11} \mathrm{E}$ desse lugar, suas análises em relação ao movimento comunista foi sempre caracterizada pela negatividade.

Segundo a tese defendida pelo autor, houve três momentos nos quais os comunistas tentaram tomar o poder no Brasil. A primeira delas teria ocorrido em 1935 com a Intentona Comunista; a segunda durante o governo de João Goulart, quando os comunistas se alinharam a uma parcela da burguesia, culminando na "contrarrevolução" de 1964 e a terceira tentativa foi na visão do autor a Guerrilha do Araguaia (1966-1974). ${ }^{12}$

Podemos inserir a produção da obra do coronel Aluísio Madruga, assim como as demais escritas ao longo dos anos 2000, dentro do contexto político e social que o Brasil passava nesse período. A partir de 2003 temos no Brasil a chegada à Presidência da República, o primeiro operário eleito de forma direta. Luiz Inácio Lula da Silva representava, assim, de certa forma, alguns ideais que a esquerda vislumbrava nas décadas de 1960 e 1970. Com ele, alguns daqueles militantes de esquerda dos anos 60 e 70, assumiram cargos importantes no governo. Podemos citar o exemplo da ministra Dilma Rousseff (Minas e Energia e, posteriormente, Casa Civil) e na Câmara dos Deputados José Genoíno Neto, que torna-se um dos principais articuladores do governo na Câmara. Ora, esse cenário político e também as medidas adotadas pelo governo, despertam em alguns setores dos militares, um posicionamento de oposição e fortes críticas ao governo. É, portanto, dentro desse contexto que se destaca a atuação do Grupo Ternuma (Terrorismo Nunca Mais), ${ }^{13}$ pois nos anos 2000, teremos uma forte atuação desse grupo através de artigos e posicionamentos em seu site na internet contra o governo e, respectivamente, suas medidas.

Podemos inferir que a produção memorialista dos militares nessa década pode estar relacionada, dentre outros fatores, a duas questões centrais. A primeira delas, uma reação à produção $e$ a publicação das memórias por parte das lideranças do PC do $\mathrm{B}$, de alguns guerrilheiros que atuaram no Araguaia $e$ as obras de jornalistas. Isto é, diante das versões das esquerdas e do silêncio do próprio estado, alguns militares perceberam a necessidade de narrarem suas versões. $E$ a segunda, as medidas tomadas pelos governos de Fernando Henrique Cardoso e Luiz Inácio Lula da Silva, que proporcionaram, por exemplo, o direito à reparação aos perseguidos políticos no período de exceção, a discussão sobre o direito à memória e à verdade e a abertura e acesso a alguns documentos da época da ditadura em nosso país. Nesse sentido, podemos destacar a homologação da lei 10.559, em 2002, durante o governo de Fernando Henrique Cardoso, garantido o direito aos perseguidos políticos a indenização por parte do Estado brasileiro e a publicação do livro "Direito à memória e à verdade", em 2007, durante o governo de Luiz Inácio Lula da Silva. ${ }^{14}$

No que concerne ao livro A guerrilha do Araguaia - revanchismo: a grande verdade, o seu prefácio é assinado pelo general Raymundo Maximiliano Negrão Torres ${ }^{15}$, o qual enfatiza o trabalho narrativo

\footnotetext{
${ }^{10}$ MOURA E SOUZA, Guerrilha do Araguaia, p. 28-29.

${ }^{11} \mathrm{O}$ Centro de Informações do Exercito (CIE) foi criado em julho de 1967 durante o governo do General Costa e Silva. O seu primeiro diretor, o coronel Adyr Fiúza de Castro, era favorável ao uso da tortura, sobretudo, psicológica. Durante o governo Médici (1969-1974), o CIE teve como diretor o coronel Milton Tavares de Sousa. Nesse período, tornou-se o órgão que mais propôs censura à televisão e a imprensa escrita. O CIE era composto por pessoas de confiança do regime militar. E, assim, tendo os comunistas como principal inimigo a ser combatido, agentes desse órgão atuaram na época da guerra no Araguaia, sobretudo, no período da chamada "Operação Sucuri". Sobre o CIE ver D'ARAUJO, Maria Celina; SOARES, Glaucio Ary Dillon; CASTRO, Celso. Introdução: rompendo o pacto do silêncio. In: Os Anos de chumbo: a memória militar sobre a repressão. Rio de Janeiro: Relume- Dumará, 1994. p. 15-16.

${ }^{12}$ MOURA E SOUZA, Guerrilha do Araguaia, p. 237.

13"TERRORISMO NUNCA MAIS" (TERNUMA) - Grupo formado por militares, ex-militares, familiares e simpatizantes, criado em 1998 "a fim de resgatar a verdadeira história da Revolução de 1964 e, mais uma vez, opor-se a todos aqueles que ainda teimam em defender os referenciais comunistas, travestidos como se fossem democráticos." Disponível em: http://www.ternuma.com.br/index.php/quem-somos Acesso em: 17 out. 14.

${ }^{14}$ BRASIL. Direito à memória e à verdade: Comissão Especial sobre Mortos e Desaparecidos Políticos. Brasília: Secretaria Especial dos Direitos Humanos, 2007.

${ }^{15}$ Raymundo Maximiliano Negrão Torres nasceu em Belém (PA), em 1925. Entrou no Exército em 1942, e durante sua carreira nessa instituição desenvolveu diversas funções atingindo a patente de general em 1978. Atuou enquanto militar no Paraná, em Brasília, no Rio Grande do Sul. Entrou para reserva em 1983, porém continuou participando da vida militar através de diversos artigos em defesa da "Revolução de 1964" e de sua instituição - o Exército. Faleceu em 2006. Disponível em: https://liciomaciel.wordpress.com/2014/09/15/general-raimundo-negrao-torres-desanca-o-mentiros-elio-gaspari/ Acesso SÆCUlUM - ReVISTA DE HistóRIa [39]; João Pessoa, jul./dez. 2018. 
de Aluísio Madruga em mostrar o papel que os militares exerceram nas tentativas de tomadas do poder político em nosso país pelos comunistas. Em seu prefácio também deixa evidente os conflitos de memórias presentes na atualidade entre os dois grupos principais envolvidos na Guerrilha do Araguaia: militares e comunistas. Os primeiros caracterizados como os "defensores da ordem" e das "instituições democráticas", e os últimos, como responsáveis pela "desordem". Assim, ao prefaciar o livro e destacar a importância narrativa da obra do coronel Aluísio Madruga para desconstruir os mitos construídos pelas esquerdas, afirmou o general Raymundo Maximiliano:

Percorre as últimas quatro décadas da história política de nosso país - às vezes com necessárias ondulações cronológicas - para mostrar, de forma resumida e ágil, os entrechoques entre defensores da lei e os que pretendiam derrubar a ordem legal. Cita fontes e transcreve o que outros escreveram, para mostrar - entre tantas coisas - como nos meandros de uma tramitação legislativa se construiu uma arma eficaz para alimentar o revanchismo que pretende transformar "bandidos" em "mocinhos" e jogar os que tiveram o duro dever de levantar do chão a luva do desafio comunista lançada à face da Nação, na rua da amargura do desprezo da sociedade, a serviço da qual deram os melhores anos de suas carreiras e, alguns, a própria vida. ${ }^{16}$

Nesse sentido, a argumentação do general Raymundo Maximiliano, demonstra, na nossa visão, todo o cerne do livro do coronel Aluísio Madruga, isto é, os conflitos e disputas presentes nas narrativas em torno dos acontecimentos da história política do Brasil pós 1964, em geral, e da própria Guerrilha do Araguaia, em específico. Narrativas estas, que na visão do general, tendem a desclassificar as Forças Armadas e a transformar os "bandidos" do passado em "mocinhos" do presente. Portanto, a obra do coronel Aluísio Madruga representa para o general uma resposta dos militares a essa versão "esquerdista" que tornou-se predominante em nosso país.

Após esse comentário geral acerca da obra do coronel Aluísio Madruga de Moura e Souza, passemos para a sua narrativa acerca da Guerrilha do Araguaia. Como o autor construiu sua versão para os acontecimentos no Araguaia? Quais as suas ênfases? Quais os aspectos comuns destacados por outros militares sobre a guerrilha? Quais questões foram silenciadas em sua narrativa? Partindo dessas indagações buscamos interpretar a versão do coronel Aluísio Madruga para a guerra no Araguaia. Há, portanto, na sua narrativa uma maior ênfase nas operações militares de combate aos guerrilheiros. Sendo um membro do Centro de Informações do Exército (CIE), na época do conflito, o autor enfatiza, inicialmente, a versão dos militares para a descoberta da guerrilha. Segundo Aluísio Madruga, já em 1969 havia uma certa suspeita dos órgãos de segurança da existência de um "trabalho de campo" que estaria sendo realizado pelo PC do B na região norte do estado de Goiás, atualmente Tocantins. Assim sendo, o Exército aproveitou o término do período de preparação de recrutas iniciado em janeiro de 1970, para realizar seus exercícios finais do Grupamento A, nessa região. Dessa forma, em novembro de 1970, teria sido organizada a "Operação Carajás". ${ }^{17}$ Para o autor, tal iniciativa mais que treinar os recrutas, servia para marcar a presença das Forças Armadas na região. E quem sabe confirmar a atuação de membros do $\mathrm{PC}$ do $\mathrm{B}$ naquela área. Contudo, a única certeza que se constatou era que a região seria propícia para o estabelecimento de uma guerrilha. ${ }^{18}$

A confirmação dessa suspeita, segundo o autor, só viria em 1972, através da prisão em Fortaleza de Pedro Albuquerque Neto e sua esposa Tereza Cristina pela Polícia Federal. A partir de seus depoimentos, os militares teriam chegado ao conhecimento da guerrilha e de sua provável localização. Organizam então, uma operação de inteligência na região sudeste do Pará que teve início com a

em: 03 mai. 17.

${ }^{16}$ TORRES, Raymundo Maximiliano Negrão. Prefácio. In: MOURA E SOUZA, Aluísio Madruga de. Guerrilha do Araguaia revanchismo: a grande verdade. Edição do Autor: Brasília, 2002, p. 10.

${ }^{17}$ Sobre essa operação militar realizada em novembro de 1970 na área onde se encontravam os militantes do PC do B, assim se refere o Relatório da Comissão Nacional da Verdade: "Em novembro daquele mesmo ano, as Forças Armadas realizariam uma manobra conjunta na região, denominada Operação Carajás. Publicamente, afirmavam que se tratava de um exercício de adestramento das tropas, isto é, de um simples exercício de treinamento na selva. No entanto, a operação tinha como objetivo o levantamento de informações sobre possíveis atividades guerrilheiras na região." Ver Relatório da Comissão Nacional da Verdade, Vol. 1, p. 687. Disponível em: http://www.cnv.gov.br/images/pdf/relatorio/volume 1 digital.pdf Acesso em: 03 mai. 17.

${ }^{18}$ MOURA E SOUZA, Guerrilha do Araguaia, p. 131. 
chegada dos primeiros agentes em Marabá (PA) no dia 25 de março de 1972 e a Xambioá (GO) em abril do mesmo ano. O autor argumenta que em alguns momentos os agentes tiveram a oportunidade de capturar suspeitos, mas devido às poucas informações que dispunham sob o grau de "subversão", não o fizeram. Contudo, essa operação teria sido suspensa devido à descoberta por parte dos guerrilheiros de sua existência. Mesmo assim, algumas prisões de guerrilheiros foram feitas $e$ destacadas pelo autor: Danilo Carneiro (Nilo), na localidade de Caiano; em Marabá Rioco Kaiano e José Genoíno Neto. ${ }^{19}$

Além de destacar as demais operações militares (setembro a outubro de 1972 e outubro de 1973 a dezembro de 1974), Aluísio Madruga narra em detalhes à estrutura organizacional dos guerrilheiros, seu modelo político - chinês, os destacamentos com sua localização e número aproximado de guerrilheiros, os comandantes da guerrilha e a comissão militar. Dessa forma, ao longo da guerra no Araguaia, os órgãos de inteligência dispunham de uma série informações sobre o movimento. É importante ressaltar que em nenhum momento o autor enfatiza o fracasso das duas primeiras operações militares para combater os guerrilheiros. Sua narrativa centraliza toda a discussão acerca da permanência dos guerrilheiros na selva, suas mortes $e$ o próprio fracasso da guerrilha a responsabilidade das lideranças do PC do B. Nesse contexto diz:

Quando os elementos operacionais das forças legais estavam psicologicamente preparados para prosseguirem em sua missão, o período previsto terminou e não havia a intenção de se permanecer na ação, porque o Exército ainda tinha a esperança de que os dirigentes da cúpula do Partido, ou seja, o Comitê Central do PC do $\mathrm{B}$ concluísse que tinha jogado um grupo de jovens, despreparados, em uma aventura suicida e que o mínimo que deveriam fazer seria determinar o abandono da área. Porém, lamentavelmente não foi assim. De maneira insana, à revelia dos demais membros do Comitê Central do Partido, os quatro membros do "Bureau Político" João Amazonas, Elza Monerat, Maurício Grabois e Ângelo Arroio - permitiram que a guerrilha prosseguisse com suas ações. ${ }^{20}$

Dessa maneira, sua versão retira dos militares a culpa pelas mortes e demais acontecimentos ocorridos no Araguaia, e coloca essa responsabilidade na cúpula do PC do B. Esse argumento não é recente entre os militares, pois desde o fim do conflito bélico no sul do Pará, geralmente alguns dos que participaram das ações de combate e resolveram externar seus posicionamentos, veem afirmando a mesma posição do coronel Aluísio Madruga. Seguindo, portanto, o mesmo argumento, o coronel Licio Augusto Maciel disse: "Grandes chefes comunistas, abandonaram seus companheiros à própria sorte numa região a que não estavam acostumados, numa selva amazônica semi-virgem, enquanto ficavam comodamente em suas salas bem refrigeradas, nas mordomias de São Paulo." ${ }^{21} \mathrm{O}$ referido autor, também faz uso de suas memórias para criticar as lideranças da guerrilha que conseguiram deixar a região do conflito abandonando os demais "camaradas". Nesse caso, as acusações recaem sobre Ângelo Arroyo (Joaquim) e Micheas Gomes Almeida (Zezinho), militantes do PC do B que segundo Licio Augusto "abandonaram covardemente seus companheiros". Assim, afirma:

Arroyo e "Zezinho" poderiam ter levado junto alguns companheiros, ou até mesmo todos, mas os abandonaram por saberem que quanto menos, maiores seriam as chances de fuga. "Zezinho" sabia como levar todos em segurança; deve ter falado com Arroyo, que optou covarde e egoisticamente pela fuga apenas dos dois. Micheas desertou com Arroyo e só reapareceu trinta anos depois (declarou que perdeu a memória ...). Seu "esquecimento" foi causado pela vergonha. ${ }^{22}$

O uso das memórias aqui é utilizado no sentido de se contrapor as afirmações das memórias construídas pelo PC do B sobre o conflito no Araguaia. Esse conflito é exacerbado e bastante evidente nas memórias de ambos os grupos (militares e PC do B). Nesse sentido, reiteramos nossa tese de que a

\footnotetext{
${ }^{19}$ MOURA E SOUZA, Guerrilha do Araguaia..., p. 133-134.

${ }^{20}$ MOURA E SOUZA, Guerrilha do Araguaia..., p. 140.

${ }^{21}$ MACIEL, Licio Augusto Ribeiro. Guerrilha do Araguaia: relato de um combatente. $2^{\mathrm{a}}$ ed. São Paulo: Schoba, 2011, p. 123.

${ }^{22}$ MACIEL, Guerrilha do Araguaia..., p. 125.
} 
guerra não terminou, ela continua muito presente nas disputas políticas, nas versões construídas, nas acusações e justificativas de ambos os lados.

$\mathrm{Na}$ guerra de memórias acerca das narrativas sobre a Guerrilha do Araguaia, uma questão que provoca trocas de acusações e sentimentos de revanchismo é o tipo de tratamento dado aos prisioneiros e aos mortos no conflito. As memórias construídas pela direção do PC do B, pelos familiares dos mortos e desaparecidos políticos e pelos moradores locais enfatizam e denunciam o caráter "desumano" dispensado aos guerrilheiros, no qual o Estado brasileiro utilizou a força para torturar, matar e ocultar os corpos dos militantes do PC do B. Na busca de dar uma resposta a essa questão, o coronel Aluísio Madruga justifica que oportunidades teriam sido dadas para que os guerrilheiros se entregassem, e aqueles presos na primeira campanha dos militares contra a guerrilha tiveram sua integridade preservada. Contudo, aos que resistiram não restou outra alternativa as forças legais, pois diante da ação dos "terroristas" a reação dos militares foi atacar. Dessa forma, argumenta:

Nas fases anteriores todas as oportunidades lhes foram dadas. Aqueles que receberam voz de prisão e sentindo que estavam em desvantagem se entregaram foram presos $e$ bem tratados. O mesmo ocorreu com os que por questões pessoais, fora da situação de combate, também se entregaram. E nem por isto receberam tratamento não condizente com o previsto neste tipo de guerra irregular. (...). E nessa nova e última fase de combate a guerrilha, as mesmas oportunidades lhes foram oferecidas. Porém, enganados inicialmente por parte do Comitê Central do PC do B que lhes informava da importância de resistirem nas posições em busca dos objetivos do Partido, e depois abandonados, os "guerrilheiros" se negavam a ser presos. ${ }^{23}$

Portanto, para o autor, a culpa pelas mortes dos militantes do PC do B não está nas forças legais, no caso, o Exército, mas na resistência dos guerrilheiros a se entregar e nas ordens recebidas pela direção do partido de resistir. Não há, assim, na versão de Aluísio Madruga maiores problemas na prática da execução dos guerrilheiros, para ele essa é uma atitude condizente com o tipo de guerra a qual eles estavam expostos, isto é, uma guerra irregular. A responsabilidade pelo que ocorreu aos guerrilheiros é atribuída ao Partido e não aos militares. Além disso, é uma visão unânime entre os militares, em especial, os quais estamos analisando suas memórias, o alcance proporcionado pela Lei de Anistia de 1979, a qual lhes assegurou o "perdão" pelas ações praticadas por estes durante o período de exceção no Brasil. ${ }^{24}$ Ao se referir a essa questão afirmou o general Francisco Batista Torres de Melo: "Derrotados no governo Médici, segue-se Geisel com o início da abertura e terminada por Figueiredo. O processo da Anistia foi o ponto de honra deste último. Anistia significa passar a borracha e começar tudo de novo". ${ }^{25}$ Portanto, segundo o general Torres de Melo, a Anistia teria "apagado" as práticas dos militares e dos grupos de esquerda durante os governos militares em nosso país. Ou seja, a função principal da Lei da Anistia, de acordo com essa afirmação do general, seria o esquecimento das ações cometidas por ambos os lados, e assim, essa questão já estaria resolvida, cabendo a partir do presente, seguir em frente, isto é, "começar tudo de novo". É importante, na nossa concepção, em relação a essa problemática, nos apropriarmos das reflexões de Paul Ricoeur em torno do uso do esquecimento motivado por questões políticas, isto é, o esquecimento comandado: a anistia. Nesse caso, o seu papel objetiva a reconciliação entre cidadãos inimigos. ${ }^{26}$ Prática geralmente utilizada em países que passaram por regimes de exceção. Entretanto, no Brasil a lei que institucionalizou a nossa anistia em 1979 é, geralmente, utilizada pelos militares no sentido de encobrir determinadas práticas de torturas e assassinatos de opositores do período da ditadura civil-militar.

Consideramos a narrativa de Aluísio Madruga, como qualquer outra, interessada. E nessa perspectiva, há uma preocupação em buscar justificar as ações dos militares na época da guerra no Araguaia, e também durante todo o período de exceção no Brasil. Essas ações são geralmente tidas como afirmativas, pois o crescimento do país em vários setores e a guerra vencida contra o comunismo

\footnotetext{
${ }^{23}$ MOURA E SOUZA, Guerrilha do Araguaia, p. 162-163.

${ }^{24}$ Lei 6.683, de 28 de agosto de 1979. Disponível em: http://www.planalto.gov.br/ccivil 03/leis/L6683.htm Acesso em: 30 out. 15.

${ }^{25}$ MELO, Francisco Batista Torres de. Buscar a verdade verdadeira. In: JIMÉNEZ, José Vargas. Bacaba II: toda a verdade sobre a Guerrilha do Araguaia e a Revolução de 1964. Campo Grande, 2011, p. 190.

${ }^{26}$ RICOEUR, Paul. A memória, a história e o esquecimento. Campinas, SP: Editora da Unicamp, 2007, p. 459. SÆCUlUM - Revista DE HistóRIa [39]; João Pessoa, jul./dez. 2018.
} 
evidenciam o "desenvolvimento e a garantia dos princípios democráticos". Por outro lado, as práticas dos grupos de esquerda são tratadas como negativas. Nesse caso, são enfatizados os sequestros, atentados, assaltos a bancos e as tentativas de guerrilhas urbana e rural.

É perceptível na escrita do coronel Aluísio Madruga indícios do uso do esquecimento e também do silêncio em determinados assuntos. Em relação ao esquecimento, percebemos sua prática a partir da ênfase do autor no tocante a Lei de Anistia, como destacamos anteriormente. No que concerne aos silêncios em sua narrativa, vejamos alguns exemplos. Dentre os "não ditos" podemos citar a prática da tortura, seja aos guerrilheiros, seja aos moradores da região; a existência da "operação limpeza" quando os corpos de alguns guerrilheiros teriam sido desenterrados e transportados para a Serra das Andorinhas, e lá queimados e de onde teriam vindo às ordens para a eliminação dos guerrilheiros. É válido destacar que outros militares através de suas memórias destacam algumas dessas práticas não enfatizadas no livro do coronel. Entretanto, a versão de Aluísio Madruga é uma visão predominante a de outros militares, as quais trataremos a seguir.

Aqui é pertinente refletir um pouco sobre esses dois conceitos, inúmeras vezes apropriados pelos pesquisadores que atuam nos estudos da construção de memórias. Partimos, inicialmente, das definições trazidas pelo dicionário. Segundo o lexicólogo Aurélio Buarque de Holanda Ferreira, esquecer significa "deixar sair da memória, pôr de lado, desprezar, tirar da memória"27, já silenciar significa "estado de quem se cala" 28 . Ao problematizar o esquecimento Paul Ricoeur enfatiza dois tipos desse fenômeno: o primeiro tipo é o esquecimento por apagamento dos rastros, isto é, aquele tipo de esquecimento que está relacionado às disfunções das operações mnésicas. Para o autor, esse esquecimento, portanto, é caracterizado enquanto uma fronteira entre o normal e o patológico. ${ }^{29}$ É, assim, o tipo de esquecimento ligado aos problemas da memória e, dessa forma, provocador das distorções da memória. Já o segundo tipo, o esquecimento reversível, ou seja, o esquecimento de reserva é caracterizado por Ricoeur enquanto uma função positiva da memória. E assim, afirma: "Em resumo, o esquecimento reveste-se de uma significação positiva na medida em que tendo-sido prevalece sobre o não mais ser na significação vinculada à ideia do passado. $O$ tendo-sido faz do esquecimento o recurso imemorial oferecido ao trabalho da lembrança." ${ }^{\prime 30}$

Ora, além desses dois tipos de esquecimentos relacionados ao caráter da operação da memória, Paul Ricoeur também analisa o esquecimento motivado por questões políticas, isto é, o esquecimento comandado: a anistia. Nesse caso, o seu papel objetiva a reconciliação entre cidadãos inimigos. ${ }^{31}$ É um recurso para estabelecer a paz após um período de exceção, por exemplo. É nesse sentido, que a prática do esquecimento é usada nos escritos dos militares, conforme podemos observar ao longo de nossa discussão.

Sobre "os não ditos", é pertinente a análise realizada por Michael Pollak classificando essa prática em três formas de lembranças: as proibidas, as indizíveis e as vergonhosas. ${ }^{32}$ Para o caso da obra do coronel Aluísio Madruga, talvez externar determinados acontecimentos praticados pelos militares durante o conflito no Araguaia, podem ocasionar perante a opinião pública atual uma visão negativa dos militares. Por essa razão, ocultá-los de sua narrativa parece ter sido, na nossa concepção, uma escolha e/ou estratégia desse autor para não comprometer as Forças Armadas.

\section{A escrita da Guerrilha do Araguaia através das memórias de um combatente}

Em 2007, o então tenente-coronel José Vargas Jiménez publicou o seu primeiro livro de memórias narrando sua participação durante a terceira campanha militar no Araguaia: Bacaba: memórias de um guerreiro de selva da Guerrilha do Araguaia. Financiado com recursos próprios, a obra, segundo o próprio autor, provocou algumas reações dentro dos setores militares, o que o teria levado a em 2011, escrever um outro livro, relatando essa repercussão: Bacaba II: toda a verdade sobre a Guerrilha do

\footnotetext{
${ }^{27}$ FERREIRA, Aurélio Buarque de Holanda. Miniaurélio Século XXI Escolar: O minidicionário da língua portuguesa. $4^{\mathrm{a}}$ ed. Rio de Janeiro: Nova Fronteira, 2001, p. 291.

${ }^{28}$ FERREIRA, Miniaurélio Século XXI Escolar, p. 636.

${ }^{29}$ RICOEUR, A memória, a história..., p. 428.

${ }^{30}$ RICOEUR, A memória, a história..., p. 451.

${ }^{31}$ RICOEUR, A memória, a história..., p. 459.

${ }^{32}$ POLLAK, Michael. Memória, esquecimento e silêncio. In: Estudos Históricos. Rio de Janeiro, vol. 2, n 3, 1989, p. 6-7.
} SÆCUlUM - Revista DE HistóRIa [39]; João Pessoa, jul./dez. 2018. 
Araguaia e a Revolução de 1964.

Para falar um pouco sobre a vida do tenente José Vargas Jiménez, utilizamos os dados biográficos contidos no seu livro de memórias "Bacaba: memórias de um guerreiro de selva da Guerrilha do Araguaia." 33 Nessa obra, temos uma breve biografia do autor, destacando, sobretudo, a sua carreira militar, cursos realizados e as funções nas quais atuou. Segundo essa obra, José Vargas Jiménez nasceu em 1948 em Corumbá - MS. Entrou para o Exército no 17º Batalhão de Caçadores (1967) em Corumbá. Em 1972, José Vargas foi transferido para a $1^{\mathrm{a}}$ Companhia do $3^{\circ}$ Batalhão de Fronteiras, na Colônia Militar do Oiapoque, com sede em Clevelândia do Norte no Amapá. Foi um militar que se aperfeiçoou na área de guerra em selva, e por isso, em 1973 foi selecionado para atuar no combate aos militantes do PC do B no Araguaia, fazendo parte da chamada terceira operação militar. ${ }^{34}$

O prefácio desse livro é feito pelo próprio autor. Nele o tenente José Vargas explica sua participação na terceira operação de combate aos membros do $\mathrm{PC}$ do $\mathrm{B}$, e cita vários documentos que serão apresentados pelo autor no decorrer do livro. Além disso, o livro também traz uma breve biografia do autor, destacando, sobretudo, de forma resumida sua carreira no Exército e as medalhas conquistadas ao longo de sua vida militar.

A narrativa de José Vargas Jiménez, enfatiza, sobretudo, sua participação na terceira operação militar, a qual participou de forma direta, fazendo incursões na mata e caçando os guerrilheiros. Assim, o autor narra as missões na selva, as prisões dos moradores locais e os combates com os guerrilheiros. Ao narrar sua primeira missão na mata, disse:

Na madrugada do dia 3 de outubro de 1973, o meu GC, o do Sgt Elizeu e do Sgt Brito, comandados por Curió e guiados por Ivan, saímos da "Casa Azul", com as missões de captura, destruição, busca e apreensão, em caminhonetas pretas do INCRA, que nos conduziram pela rodovia Transamazônica, até o povoado de Bom Jesus, onde, após cercá-lo, entramos de casa em casa, fazendo prisioneiros, os camponeses que apoiavam os guerrilheiros, que totalizaram aproximadamente trinta, todos suspeitos de dar cobertura e apoiar os guerrilheiros. ${ }^{35}$

Percebemos, portanto, uma preocupação do autor ao narrar de forma minuciosa as operações militares no Araguaia, descrevendo os acontecimentos e o cotidiano dos militares na sua relação com os moradores locais, inclusive as prisões de alguns que teriam sido levantados pela "Operação Sucuri" comprovando suas ligações com os guerrilheiros. O livro também traz transcritos alguns documentos que teriam sido utilizados pelos soldados nessa terceira campanha militar. Segundo o autor, eles teriam sido produzidos pelo Centro de Informações do Exército (CIE) e distribuídos para cada soldado nessa terceira fase das operações de combate aos guerrilheiros. Esses documentos se referem: Plano de captura e destruição, no qual estavam relacionados todos os grupos de guerrilheiros que atuavam na região; Plano de busca e apreensão, trazia a relação dos camponeses com alguma ligação com os guerrilheiros, as localidades onde estes deveriam ser feitos prisioneiros e o grau de prioridade de captura, variando de um (1) a quatro (4) e Trato com a população, no qual eram destacadas normas de como o soldado deve tratar os moradores locais, além de enfatizar como essa população era utilizada pelos guerrilheiros para que eles alcançassem seus objetivos. ${ }^{36} \mathrm{Em}$ sua versão o tenente José Vargas relata de forma objetiva as mortes de alguns guerrilheiros e militares durante as campanhas de combate à guerrilha. Contudo, o que nos chamou mais a atenção em sua narrativa é a descrição da prática de "interrogatório" utilizada pelos militares para conseguir as informações dos moradores da região acerca dos guerrilheiros. Ao se referir ao tratamento dispensado pelos militares aos moradores locais, disse José Vargas:

Certa vez "Curió" saiu com meu GC a fim de confirmar informação de um encontro entre guerrilheiros e um camponês que os apoiava. Preparamos uma emboscada no local, porém só apareceu o camponês de nome Frederico Lopes que foi feito prisioneiro. Foi interrogado no mesmo local por métodos convencionais e como se

\footnotetext{
33 JIMÉNEZ, José Vargas. Bacaba: memórias de um guerreiro de selva da Guerrilha do Araguaia. Campo Grande, 2007.

34 JIMÉNEZ, Memórias de um guerreiro de selva..., p. 26-27.

35 JIMÉNEZ, Memórias de um guerreiro de selva..., p. 41.

${ }^{36}$ JIMÉNEZ, Memórias de um guerreiro de selva..., p. 36-40.
} 
recusou a falar sobre qual grupo de guerrilheiros estava esperando $e$ o assunto que tratariam, recebemos ordens para mudar a tática de interrogatório. Foi então amarrado nu, num pau viveiro de formigas (pau-de-arara) e seu corpo lambuzado com açúcar e sua boca cheia de sal. Quando as formigas começaram a andar pelo seu corpo e picá-lo, nos relatou tudo o que queríamos saber. Depois o desamarramos, retiramos do pau-de-arara, deixamos que tomasse banho num igarapé e o conduzimos prisioneiro para nossa base em Bacaba. ${ }^{37}$

A escrita do tenente José Vargas, descreve, a nosso ver, uma prática comum utilizada durante a Guerrilha do Araguaia - a tortura aos moradores locais. Assunto geralmente pouco comentado nas narrativas dos militares. Alguns preferem não se referir, e quando questionados sobre sua existência, buscam minimizar tal prática utilizando para isso a tese da chamada "guerra suja". Em sua descrição, José Vargas usou o recurso do eufemismo "interrogatório", para se referir a essa prática junto aos moradores do Araguaia. Sua descrição é a prova do sofrimento da população local diante do "fogo cruzado" entre militares versus guerrilheiros e a sua limitação de não ter a quem apelar. São agentes que cometem a tortura em nome do Estado brasileiro.

Consideramos que a narrativa do tenente José Vargas Jiménez difere em algumas questões das demais narrativas de seus pares. Pois ele destaca práticas não abordadas e/ou negadas por outros militares que também chegaram a publicar suas memórias. Uma delas conforme podemos observar na citação é o uso da tortura aos moradores da região e aos guerrilheiros presos durante as operações militares. Dessa forma, sua escrita soa enquanto dissonante em relação as narrativas dos demais militares aqui estudadas.

Além de afirmar que houve casos de guerrilheiros que foram presos e depois mortos, contrariando a versão oficial das Forças Armadas e, também de muitos militares que externaram suas versões sobre a guerra no Araguaia, e que insistem na tese de que os guerrilheiros foram mortos em combate, o tenente José Vargas descreve o que denomina de "técnicas de interrogatório", na nossa concepção, práticas de torturas, as quais eram submetidos os prisioneiros. Assim diz:

As técnicas de interrogatório a que eram submetidos os guerrilheiros em Bacaba consistiam em: choques com corrente elétrica gerada por baterias de telefone de campanha portáteis; telefone (consistia em dar tapas com força, simultaneamente nos dois ouvidos com as mãos abertas); colocá-los em pé, descalços em cima de duas latas de leite condensado se apoiando somente com um dedo na parede; socos em pontos vitais tais como no fígado, rins, estômago, pescoço, rosto e cabeça, além de fazê-los passar fome e sede. ${ }^{38}$

É oportuno frisar que essa afirmação provocou estranhamento por parte dos demais militares, e, sobretudo, pelas lideranças do Exército, mas evidencia em nosso estudo, o caráter heterogêneo e múltiplo das memórias e versões dos militares acerca da atuação das Forças Armadas no Araguaia. Além disso, confirma que entre os militares existem múltiplos grupos, com posições diferenciadas em algumas questões. Demonstra também o caráter autoritário do estado brasileiro, nesse período, que permitiu que em nome da "democracia" e para se combater o inimigo "o comunismo", pessoas fossem acusadas e torturadas sem o direito de se defenderem. Por outro lado, a visão oficial de boa parte dos militares argumenta que a violência também era praticada pelos guerrilheiros, "terroristas" $e$ comunistas como são adjetivados.

A narrativa do tenente José Vargas também traz alguns aspectos do cotidiano dos militares e dos moradores locais. Embora não aprofunde esses aspectos, sua versão nos leva a perceber as relações estabelecidas entre soldados e moradores da região, especificamente, nas relações pessoais. Geralmente, as narrativas acerca da guerrilha por parte dos militares privilegiam as batalhas, as prisões, as mortes e as estratégias utilizadas para vencer o inimigo - o comunismo. Porém, mesmo que de forma superficial, José Vargas cita algumas práticas dos militares nos momentos que estes não estavam em combate no meio da selva, ou seja, nos momentos de folga. Assim, afirma o autor:

\footnotetext{
${ }^{37}$ JIMÉNEZ, Memórias de um guerreiro de selva..., p. 64. Na narrativa do autor GC significa grupo de combate.

${ }^{38}$ JIMÉNEZ, Memórias de um guerreiro de selva..., p. 56.

SÆCULUM - REvista DE HistóRIa[39]; João Pessoa, jul./dez. 2018.
} 
A cada dois meses que os GC ficavam na selva combatendo guerrilheiros eram dispensados, juntamente com seu comandante, por dois dias, pra irem à cidade de Marabá-PA, fazerem "higiene mental", divertir-se e fazer outras necessidades fisiológicas que o corpo humano pede, nas casas noturnas e boates da cidade. ${ }^{39}$

Podemos observar como características da escrita do autor sua linguagem coloquial, simples $e$ objetiva. Ele não faz uso de eufemismos para narrar determinadas práticas dos militares no Araguaia, opta por uma descrição mais direta, por exemplo, quando se refere a tortura praticada aos moradores da região e aos guerrilheiros, os momentos de lazer da tropa e a forma como se refere as mortes dos militantes do PC do B. A sua narrativa embora apresente práticas ocultadas por outros militares que publicaram suas versões, não foge a regra dos seus pares externando uma visão linear, anticomunista $e$ autoritária. É uma linguagem, muitas vezes, estranha de nossa parte, mas que reflete as ideias e os costumes dos militares que lutaram contra a guerrilha naquela época. Nesse sentido, sua escrita ao mesmo tempo que choca o leitor, também provoca nele a atenção e a curiosidade pela conclusão de sua trama. Talvez, esse tenha sido o recurso utilizado pelo tenente José Vargas para que o seu livro alcance um maior número de leitores e a sua versão tenha legitimidade.

A versão publicada pelo tenente José Vargas Jiménez chamou na época a atenção da imprensa. Nesse sentido, a Revista Isto É, edição de 12 de novembro de 2008, publicou uma matéria do jornalista Alan Rodrigues sob o título "A tropa do extermínio", na qual são destacadas a narrativa do tenente acerca da luta armada no Araguaia, documentos da época presentes no seu livro e publicados na reportagem e uma entrevista com o autor. ${ }^{40} E$ E oportuno frisar que a entrevista concedida pelo tenente José Vargas Jiménez a essa revista de circulação nacional, confirmou a sua narrativa publicada no seu livro "Bacaba: memórias de um guerreiro de selva da Guerrilha do Araguaia", servindo, assim, enquanto um meio de divulgação de sua obra.

\section{A versão da Guerrilha do Araguaia através da narrativa de Licio Maciel}

Assim como o tenente José Vargas Jiménez, outro combatente no Araguaia que escreveu sua versão acerca da Guerrilha do Araguaia foi o coronel Licio Augusto Ribeiro Maciel ("Dr. Asdrúbal"), como ficou conhecido na região. Seu livro, publicado em 2008, trouxe como título Guerrilha do Araguaia: relato de um combatente. Nessa obra, o próprio subtítulo já nos dá uma ideia de testemunho "relato de um combatente". É, portanto, a narrativa de um militar que esteve no palco da guerra e, sobretudo, atuou nela. Nesse caso, sua versão para os fatos ocorridos no Araguaia, tem um caráter de "verdade" ao contrário de outros militares que apenas produziam "relatos fictícios" sobre a guerrilha. ${ }^{41}$ Esse seu livro pode ser interpretado também como uma resposta à versão construída pelo jornalista Luiz Maklouf Carvalho a experiência do coronel Licio Augusto na guerrilha, quando publicou o livro "O coronel rompe o silêncio". ${ }^{42}$ Nesse sentido, Licio Augusto faz várias críticas a essa obra do jornalista Luiz Maklouf. Escolhemos aqui, aquela que sintetiza uma visão que consideramos ao mesmo tempo irônica e também pitoresca da crítica do coronel ao jornalista:

O jornalista Luiz Maklouf Carvalho, escreveu o livro "O Coronel Rompe o Silêncio Licio Augusto Ribeiro, que matou e levou tiros na caçada aos guerrilheiros do Araguaia, conta sua história" - (isto é lá título de livro? Só vi semelhante em história de cordel em Caruaru). Baseado em minhas declarações, mas distorceu muitos fatos, fez comparações com falsas, suspeitas e mentirosas testemunhas, cortou muito do que foi por mim declarado, enfim, fez o que quis, com o objetivo de tirar o conteúdo dos fatos reais. Só o extenso título do livro já diz qual o objetivo do autor. ${ }^{43}$

\footnotetext{
${ }^{39}$ JIMÉNEZ, Memórias de um guerreiro de selva..., p. 68.

${ }^{40}$ RODRIGUES, Alan. A tropa de extermínio. Isto É. São Paulo, Edição no 2036, 12 de novembro de 2008. Disponível em: http://www.istoe.com.br/reportagens/paginar/1866_A+TROPA+DO+EXTERMINIO/1 Acesso em: 25 set.14.

${ }^{41}$ Nesse sentido, o coronel Licio Augusto Maciel faz várias críticas à narrativa de Pedro Corrêa Cabral, considerando sua versão enquanto fictícia. Sua crítica se refere a versão dada pelo capitão aviador Pedro Corrêa Cabral através do seu livro Xambioá: Guerrilha no Araguaia, publicado pela Editora Record em 1993.

${ }^{42}$ CARVALHO, Luiz Maklouf. O coronel rompe o silêncio. São Paulo: Objetiva, 2004.

${ }^{43}$ MACIEL, Guerrilha do Araguaia: relato de um combatente, p. 267. 
Portanto, ao publicar sua versão em 2008, o coronel Licio Augusto, pretende mostrar o conteúdo verdadeiro para os acontecimentos passados no Araguaia, e nesse sentido, sua obra entra em conflito com o livro publicado pelo jornalista, que segundo o coronel teria "distorcido" e "cortado" os fatos por ele narrados.

Quem é o coronel Lício Augusto Ribeiro Maciel? Qual a sua participação no combate a luta armada no Araguaia? Os dados biográficos desse militar foram extraídos do livro do jornalista Luiz Maklouf Carvalho, O coronel rompe o silêncio. Segundo esse jornalista, Licio Maciel nasceu em Maceió - AL em 4 de junho de 1930, em uma família que dispunha de um certo capital econômico e intelectual. Seu pai era advogado e escritor e foi um dos fundadores da Academia Alagoana de Letras. Desde cedo, Licio Augusto despertou o interesse pela matemática e apresentava uma tendência para a área da engenharia. Com a morte do pai, em 1950 a vida da família tornou-se mais difícil, obrigando seus irmãos mais velhos e sua mãe a trabalharem. Aos 19 anos ingressou no Instituto Tecnológico de Pernambuco desejando ser engenheiro, mas não concluiu o curso. Mudou-se para o Rio de Janeiro e prestou exames para a Escola Militar de Rezende onde se formou. A partir dai, seguiu a carreira militar, geralmente se destacando nos cursos que realizava. ${ }^{44}$

Ainda tendo como fonte as informações colhidas pelo jornalista Luiz Maklouf, em 1959, Licio Maciel foi admitido na Escola Técnica do Exército, posteriormente, Instituto Militar de Engenharia (IME), onde formou-se engenheiro de comunicação em 1963. Em 1964, foi trabalhar na $9^{a}$ Região Militar, em Campo Grande, na época Mato Grosso, com a tarefa de estabelecer ali a rede de rádio. A partir de 1968 entrou para o Centro de Informações do Exército (CIE) e adotou o codinome de "Dr. Asdrúbal", como se tornou conhecido na época da guerra no Araguaia. Antes de iniciar os combates no Araguaia, Licio Maciel recebeu do coronel Carlos Sérgio Torres, a missão de ir de carro de Brasília a Belém (PA) com uma turma do Ministério dos Transportes. O objetivo dessa missão, realizada em 1969, era sondar se havia algo de estranho nessas regiões, ou seja, identificar possíveis focos de guerrilha. Na década de 1970, durante a Guerrilha do Araguaia, participou das principais operações de combate aos militantes do PC do B. ${ }^{45}$

O prefácio do seu livro é assinado pelo ex-ministro do governo militar Jarbas Passarinho. Nele o exministro tece uma série características do coronel Licio Augusto na época em que atuou no Exército brasileiro, e em especial, durante a Guerrilha do Araguaia. Assim disse: "Cadete sério, sociável, de conduta exemplar, compenetrado, bom aluno, de elevado espírito militar, cumpridor das obrigações e muito disciplinado (...)."46

Consideramos o prefácio dessa obra importante, pois a partir dele já observamos a disputa em torno do passado da luta no Araguaia. Dessa maneira, após uma breve apresentação do autor, o exministro Jarbas Passarinho faz uma série de criticas aos militantes de esquerda e, sobretudo, as práticas desses, na época dos governos militares. Nesse contexto, afirma:

O assassinato do Soldado Mário Kozel Filho, explodido quando de sentinela ao QG do II Ex, não é considerado crime. O atentado no Aeroporto dos Guararapes, no Recife, não teve importância, foi apenas uma brincadeirinha que resultou na morte de um jornalista, de um almirante e deixando centenas de feridos e mutilados. ${ }^{47}$

Portanto, o ex-ministro Jarbas Passarinho deixa bem claro em seu prefácio, o tom da narrativa que o leitor terá acesso nas próximas páginas da obra. Esse prefácio também evidencia a guerra de memórias personificadas nessa citação pelas acusações feitas aos grupos de esquerda nos atentados praticados pelos mesmos durante as décadas de 1960 e 1970. Ao se referir as narrativas acerca da Guerrilha do Araguaia, em especial, a escrita de sua história, disse:

A História do Araguaia será escrita por historiadores confiáveis, seguramente de formação e reputação ilibadas, no tempo correto da historiografia. Não adianta os comunistas quererem inventar uma versão mentirosa e empurrá-la goela abaixo do

\footnotetext{
${ }^{44}$ CARVALHO, O coronel rompe o silêncio, p. 27-30.

${ }^{45}$ CARVALHO, O coronel rompe o silêncio, p. 33-36.

${ }^{46}$ PASSARINHO, Jarbas Gonçalves. Prefácio. In: MACIEL, Licio Augusto Ribeiro. Guerrilha do Araguaia: relato de um combatente. $2^{\mathrm{a}}$ ed. São Paulo: Schoba, 2011, p. 15.

${ }^{47}$ PASSARINHO, Prefácio. In: MACIEL, Guerrilha do Araguaia: relato de um combatente, p. 19.
} SÆCUlUM - REvista DE HistóRIa [39]; João Pessoa, jul./dez. 2018. 
brasileiro, que pode ser tudo menos imbecil. ${ }^{48}$

Vemos, assim, na afirmação do ex-ministro Jarbas Passarinho no prefácio da obra do coronel Licio Augusto Maciel, fortes indícios das constantes disputas de memórias que envolvem as narrativas concernentes à Guerrilha do Araguaia. A versão do coronel, nesse sentido, tem um objetivo de lançar a sociedade à história desse acontecimento a partir do testemunho de alguém que esteve lá, isto é, o seu lugar de narrador é institucionalizado por aquilo que Beatriz Sarlo denomina de retórica testemunhal, pois aquele que narra esteve ali aonde os fatos aconteceram. ${ }^{49}$ Dessa forma, sua narrativa, assim como as demais construídas e publicadas por outros militares se institucionaliza enquanto verdadeira.

Para situar os leitores do seu lugar de fala - "relato de um combatente" - já na introdução do seu livro, o coronel Licio Augusto define o que ele considera como Guerrilha do Araguaia: "A Guerrilha do Araguaia foi uma tentativa armada do Partido Comunista do Brasil (PC do B) de tomada do poder, visando à implantação do regime comunista no nosso país". ${ }^{50}$ Essa definição para o movimento armado no Sul do Pará durante a década de 1970, é unânime entre os militares que publicaram suas versões sobre esse acontecimento. Na nossa concepção foi uma maneira encontrada pelos militares para demarcar o seu lugar na disputa pelo passado desse acontecimento, enfatizando, dessa forma, o papel exercido por estes para impedir que o Brasil se tornasse um país comunista. Ou seja, na construção da versão militar para a Guerrilha do Araguaia, a vitória final pelas armas significou a vitória do capitalismo e dos seus valores sobre o comunismo. São esses valores, portanto, que os leitores encontrarão através de sua narrativa.

A versão apresentada pelo coronel Licio Augusto, é de certa forma, semelhante em alguns aspectos, a narrativa do coronel Aluísio Madruga. Dos militares que até então publicaram suas memórias, o coronel Licio Augusto foi um dos que mais tempo atuou no combate aos militantes do PC do B no Araguaia. Seu contato com a região palco da guerra, segundo o próprio coronel, começou em 1969, quando realizou a serviço dos órgãos de inteligência do Exército uma viagem através da rodovia Belém - Brasília (BR 153), com o intuito de localizar possíveis áreas de treinamento de guerrilha. Nessa missão, Licio Augusto passou-se por engenheiro da Embratel e percorreu sítios e fazendas, entrou em contato com fazendeiros e demais pessoas da região. Contudo, nada de concreto foi encontrado, apenas suspeitas. Em 1970, o coronel Licio Augusto participou como observador da Manobra Marabá $70^{51}$, e nessa oportunidade teria tido oportunidade de visitar várias áreas da região e mantido contato com os moradores. Assim narra:

Os fazendeiros e moradores da mata tinham notícias de muita gente esquisita em diversos locais, fazendo tudo menos atividades agrárias ou semelhantes. No final, eu era capaz de garantir que eles, os discípulos de Marighela, estava lá. O problema é que eu não tinha provas concretas, o argumento principal de convencimento, principalmente no meio militar. ${ }^{52}$

Assim como o coronel Aluísio Madruga, Licio Augusto atribui à descoberta da área da guerrilha a prisão de Pedro Albuquerque Neto e sua esposa Tereza Cristina. É perceptível na narrativa do coronel Licio a disputa política existente no presente entre os que estiveram com o poder na época da guerrilha e os que hoje fazem parte do poder no Brasil. Ao citar como exemplos o caso dos guerrilheiros, Pedro Albuquerque (Jesuíno) e José Genoíno (Geraldo), ambos presos pelos militares durante as primeiras

\footnotetext{
${ }^{48}$ PASSARINHO, Prefácio. In: MACIEL, Guerrilha do Araguaia: relato de um combatente, p. 20.

${ }^{49}$ SARLO, Beatriz. Tempo Passado: cultura da memória e guinada subjetiva. Tradução de Rosa Freire d'Aguiar. São Paulo: Companhia das Letras; Belo Horizonte: UFMG, 2007, p. 50.

${ }^{50}$ MACIEL, Guerrilha do Araguaia: relato de um combatente, p. 27.

${ }^{51}$ Segundo o coronel Aluisio Madruga, em janeiro de 1970 o Exército Brasileiro realizou na região de Marabá (Sudoeste do Estado do Pará) uma operação de treinamento de soldados recrutas incorporados naquele ano. Essa operação teria sido realizada nessa região diante das suspeitas ainda não confirmadas, nesse período, de focos de guerrilha. Entretanto, essa operação nada teria confirmado nesse sentido. É importante destacar que em novembro desse mesmo ano, o Exército também realizou nessa mesma área uma outra operação denominada na época de "Operação Carajás", mas até esse momento, nada teria sido confirmado pelos militares, segundo o coronel. Ver MOURA E SOUZA, Guerrilha do Araguaia, p. 131.

${ }^{52}$ MACIEL, Guerrilha do Araguaia: relato de um combatente, p. 31. 
investidas contra a guerrilha, o coronel Licio faz fortes críticas a postura política e ética dos dois, e tece elogios aos militares. Dessa forma, diz:

Estive com ambos em minhas mãos, a mais de cem quilômetros para dentro das matas do Pará, no comando de uma equipe de cerca de oito militares. É fácil imaginar tudo que poderia ter acontecido aos dois. Um, tentando negar que fazia parte do bando, tentando inclusive fugir e não obedecendo aos tiros de advertência para o ar, sendo pegado em seguida enredado no cipoal, poderia facilmente ter sido "feito" legalmente, pois tentou fugir; o outro, já tendo confessado e cortado os pulsos por medo de ser justiçado pelos próprios companheiros, como confessou, poderia ter tido o mesmo destino (...). No entanto, estão aí os dois "lépidos e fagueiros", mentindo e tentando aviltar a Instituição que lhes salvou a vida. ${ }^{53}$

Há, portanto, nas afirmações do coronel Licio Augusto fortes indícios de ressentimento e disputas políticas. As memórias são aqui usadas para criar uma imagem positiva dos militares, “... a Instituição que lhes salvou a vida" e ao mesmo tampo, acusar os ex-guerrilheiros de não serem coerentes com suas versões acerca do que lhes teria acontecido no Araguaia. ${ }^{54}$ Ora, tais evidencias, na nossa concepção, reforça nossa tese de que a "guerra ainda não terminou", pois ao longo desses quarenta anos após o fim do conflito bélico, como estamos observando ao longo de nossa discussão, os ataques são constantes, hoje não mais por meio das armas, mas através dos discursos, das acusações, dos ressentimentos e das narrativas de memórias construídas através dos livros.

Há ao longo de sua narrativa várias acusações às lideranças do PC do B que recrutaram jovens para organizar uma guerrilha e implantar no Brasil o comunismo. Dessa forma, afirma: "As raposas velhas do $\mathrm{PC}$ do $\mathrm{B}$ desviaram os jovens, os iludiram e os abandonaram à própria sorte nas selvas do Pará, fugindo antes do primeiro tiro e aboletando-se no conforto das cidades." ${ }^{55}$ Com essa afirmação, o autor responsabiliza os líderes do partido pelas consequências da resistência dos guerrilheiros às forças oficiais, ao mesmo tempo tece uma crítica contundente a esses líderes que fugiram $e$ abandonaram esses jovens a própria sorte. Evidentemente, que não deixa de ser uma estratégia interessada dos militares no sentido de não se responsabilizarem pelos fatos ocorridos durante a guerra.

O autor narrando do seu lugar de militar, evidentemente, priorizou na obra os aspectos dos combates e das operações militares durante o seu período na região da guerrilha. Como militar ver a guerra de forma natural, sem grandes problemas, diferentemente de como a população civil percebe um conflito bélico. Nesse sentido, há uma afirmação na sua obra que sintetiza essa sua visão de homem de guerra. Assim afirma: "A guerra é, definitivamente, parte integrante da existência humana. A história da Humanidade é a história das guerras" ${ }^{56}$ Ora, não poderíamos nesse contexto deixar de comparar sua máxima, a afirmação marxista de que "toda história é a história da luta de classes". Para o coronel Licio Augusto, o motor da história não está na luta de classes como afirmava Marx, mas nas guerras. Elas movem os seres humanos e ele como os demais militares que atuaram no Araguaia estavam dispostos a cumprir esse princípio. Para justificar o seu determinismo bélico, o autor cita exemplos das inúmeras guerras realizadas pelos seres humanos desde o princípio da história da humanidade até o período contemporâneo. Essa sua visão não deixa de ser uma contraposição ao princípio marxista da ideia de luta (revolução) para se instituir o comunismo. E nesse aspecto, a guerra enfatizada e praticada por Licio Augusto e os outros militares no Araguaia, era afinal, para se combater esse sistema.

Ao contrário do que hoje é defendido pelas organizações de direitos humanos, o coronel Licio Augusto é enfático em suas posições em relação aos acontecimentos da Guerrilha do Araguaia. Defendendo a tese de guerra, mesmo que ela tenha sido do tipo irregular, ou seja, guerra de guerrilhas, o autor não considera que houve "abusos" por parte dos militares que atuaram no Araguaia. Os procedimentos lá adotados são considerados normais em caso de guerra pelo coronel.

\footnotetext{
${ }^{53}$ MACIEL, Guerrilha do Araguaia: relato de um combatente, p. 32-33.

${ }^{54}$ Sobre José Genoíno, ver COELHO, Maria Francisca Pinheiro. José Genoíno: escolhas políticas. $1^{a}$ ed. São Paulo: Centauro, 2007.

${ }^{55}$ MACIEL, Guerrilha do Araguaia: relato de um combatente, p. 44.

${ }^{56}$ MACIEL, Guerrilha do Araguaia: relato de um combatente, p. 145.
} 
Buscando defender os militares, diz Licio Augusto:

(...) Falar que os militares agiram como bárbaros no Araguaia é demonstrar ignorância total em assuntos de guerra ou muita pusilanimidade. Pegar terrorista escondido na mata nunca foi fácil. Se eles tivessem um mínimo de competência, teria morrido muito maior número dos nossos, sem a mínima dúvida. Eles mesmos hoje em dia reconhecem que eram um bando de incompetentes. ${ }^{57}$

No campo da guerra de memórias, Licio Augusto e também outros militares que publicaram suas versões acerca da guerrilha, buscando construir o seu lugar no cenário das memórias, geralmente enfatizam a vitória final dos militares através das armas e tentam demonstrar que a derrota sofrida pelo PC do B deu-se por "incompetência" dos guerrilheiros. E para reafirmar esse posicionamento, atribui aos atuais líderes do partido, o próprio reconhecimento desse fato - "(...) Eles mesmos hoje em dia reconhecem que eram um bando de incompetentes". Ora, não sabemos precisar baseado em qual declaração dos líderes do PC do B, Licio Augusto se refere nessa afirmação, mas o que fica evidente nela é o fato de acusar os militantes do partido de ontem e de hoje pela derrota que sofreram.

$\mathrm{Na}$ visão do coronel, a guerra foi a responsável pelos atos ocorridos durante o conflito no Araguaia. Os militares apenas cumpriam a sua missão de defender a pátria contra o "grande mal" que pairava sobre a sociedade naquele período - o risco do país tornar-se comunista. E na guerra conta os defensores desse sistema político, a violência existiu de ambos os lados, da parte dos militares e da parte dos guerrilheiros. E nesse caso, quando o autor faz referência a violência praticada pelos militantes do PC do B, inúmeros exemplos são enfatizados, seja durante a Guerrilha do Araguaia, seja em outros momentos históricos ocorridos no Brasil, como é o caso da "Intentona Comunista", do atentado no aeroporto dos Guararapes, em Pernambuco, dos vários assaltos a bancos e sequestros arquitetados pelos grupos de esquerda. Em relação à Guerrilha do Araguaia, em específico, Licio Augusto destaca o justiçamento de um filho de um camponês, por ter contribuído com as forças legais, a morte do cabo Odílio da Cruz Rosa e do soldado Francisco Valdir de Paula. E assim conclui "Em nenhum país no mundo onde tenha ocorrido guerrilha, as ações violentas ou estranhas foram praticadas só por um dos lados." 58 Dessa forma, na concepção do coronel Licio Augusto, as ações violentas praticadas durante o conflito foram de ambos os lados, característica da chamada "guerra suja", na qual as convenções internacionais deixam de ser consideradas. A crítica externada pelo autor se refere, principalmente, ao reconhecimento por parte dos militantes do PC do B em admitir esses atos de violência que teriam praticado durante o conflito.

Um aspecto comum nos livros dos militares conforme podermos observar ao longo desse artigo, é a afirmação que a luta no Araguaia representava a batalha contra o comunismo e em defesa da democracia. Entretanto, cabe ressaltar, qual a concepção de democracia defendida por estes militares? A historiadora Lucileide Cardoso através do seu estudo acerca das criações da memória dos defensores e críticos da ditadura militar, nos apresenta cinco características da concepção de democracia presente entre os militares: responsabilidade, honestidade, ordem, progresso e luta contra a "subversão". ${ }^{59}$ São esses, portanto, o ideário de democracia defendidos pelos autores estudados nesse artigo. Motivo segundo eles, da sua participação no enfrentamento aos terroristas no Araguaia.

É importante ressaltar ainda nos livros dos militares aqui estudados, algumas informações relacionadas às editoras que os publicaram, pois com exceção da obra do capitão aviador Pedro Corrêa Cabral, publicada pela Editora Record, os demais livros foram publicados ou por iniciativa de cada autor, isto é, particular (o caso, por exemplo, de Aluísio Madruga de Moura e Sousa e José Vargas Jiménez) ou através de editoras pequenas como o do livro do coronel Licio Augusto, publicado pela Editora Schoba da cidade de Salto em São Paulo. Dessa maneira, observamos que as produções das obras dos militares são mais simples, sem o apoio e a divulgação de editoras maiores que controlam o mercado editorial brasileiro. Podemos inferir, diante desse quadro, que esses livros em comparação com os dos jornalistas e também intelectuais de esquerda, como por exemplo, Guerra de

\footnotetext{
${ }^{57}$ MACIEL, Guerrilha do Araguaia: relato de um combatente, p.196.

${ }^{58} \mathrm{MACIEL}$, Guerrilha do Araguaia: relato de um combatente, p.197.

${ }^{59}$ CARDOSO, Lucileide. Criações da memória: defensores e críticos da ditadura (1964-1985). Cruz das Almas - BA: UFRB, 2012 , p. 132.
} 
Guerrilhas no Brasil: a saga do Araguaia, de Fernando Portela, publicado pela Global Editora em 1979 e Combate nas Trevas - A esquerda brasileira: das ilusões perdidas à luta armada, de Jacob Gorender, publicado em 1987 através da Editora Ática, obtiveram uma circulação mais restrita.

Embora os estilos narrativos de cada autor sejam peculiares, identificamos nas obras dos militares analisadas nesse trabalho alguns pontos em comum. Dentre eles podemos destacar a ideia de se construir uma narrativa que se pretende "verdadeira" em oposição às versões construídas pelas esquerdas, tidas por eles enquanto "fantasiosas e falsas". São defensores da atuação das Forças Armadas no combate aos guerrilheiros, pois estes representavam a "desordem e o atraso" para o país. Já as Forças Armadas representam o contrário, "a ordem e o progresso" da nação. Nesse sentido, ao defenderem a sua instituição, acusam através de suas narrativas as lideranças do PC do B, no passado e também no presente, pelas mortes ocorridas durante a Guerrilha do Araguaia. Os autores aqui analisados também defendem o esquecimento para os atos cometidos durante o período de exceção no Brasil, de forma geral, e em específico, para aqueles praticados durante a Guerrilha do Araguaia. Para eles a Lei de Anistia sancionada durante o governo do general João Baptista Figueiredo em 1979, teria resolvido todas as questões sejam elas por parte dos militares, sejam por parte dos militantes de esquerda. Assim sendo, são críticos e contrários a prática da reparação aos perseguidos políticos garantida através da lei 10.559, sancionada no governo Fernando Henrique Cardoso. 


\section{RESUMO}

O presente artigo faz uma reflexão acerca da construção das memórias dos militares que atuaram de forma direta e/ou indireta no conflito armado no Araguaia na década de 1970. Conflito este nomeado tanto pelas esquerdas quanto pelos militares como "Guerrilha do Araguaia". Através da publicação de livros, alguns militares vêm tornando pública as suas versões para esse acontecimento da história contemporânea do Brasil, e, com essa prática, provocando uma disputa em torno das memórias desse conflito que envolveu diversos sujeitos: militantes do Partido Comunista do Brasil ( $\mathrm{PC}$ do $\mathrm{B})$, militares e moradores da região. Nesse sentido, partimos da ideia que embora a guerra tenha sido concluída no final de 1974 , a construção de suas memórias, em especial, através da escrita $e$ publicação de livros, tem evidenciado uma continuidade dessa guerra, não mais pelas armas, mas através das narrativas constantes nesses livros até os dias atuais. $\mathrm{O}$ artigo busca discutir as disputas pelo passado da luta armada no Araguaia a partir da narrativa de três obras, escritas e publicadas por militares nos anos 2000.

Palavras-chave: Disputa pelo passado; Militares; Livros.

Artigo recebido em 23 out. 2017.

Aprovado em 16 mai. 2018.
ABSTRACT
This article reflects on the construction of memories of the military personnel who acted directly and/or indirectly in the armed conflict in the Araguaia in the 1970s. This conflict was named by both the left and the military as the "Araguaia Guerrilha". Through publication of books, some soldiers have been publishing their versions for this event in the contemporary history of Brazil and thus, provoking a dispute around the memories of this conflict that involved several subjects: militants of the Communist Party of Brazil (PC do B), military and residents of the region. In this sense, we start from the idea that although the war was completed at the end of 1974, the construction of memoirs, especially through the writing and publication of books, has evidenced a continuity of this war, no longer through arms, but through narratives in these books to this day. The article seeks to discuss the past disputes of the armed struggle in Araguaia from the narrative of three works, written and published by the military in the years 2000 .

Keywords: Dispute for the past; Military; Books. 